\title{
Roles of flower scent in bee-flower mediations: a review
}

\author{
Daniel Bisrat ${ }^{1,2 *}$ (ID and Chuleui Jung ${ }^{1,3}$ (iD) \\ 'Department of Plant Medicals, Andong National University, Andong 36729, Republic of Korea \\ 2Department of Pharmaceutical Chemistry and Pharmacognosy, School of Pharmacy, Addis Ababa University, Addis Ababa P.O. Box 1166, Ethiopia \\ ${ }^{3}$ Agriculture Science and Technology Research Institute, Andong National University, Andong 36729, Republic of Korea
}

\section{ARTICLE INFO}

Received September 29, 2021

Revised November 15, 2021

Accepted November 15, 2021

Published on January 21, 2022

*Corresponding author

Daniel Bisrat

E-mail daniel.bisrat@aau.edu.et
Background: Bees and flowering plants associations were initially began during the early Cretaceous, 120 million years ago. This coexistence has led to a mutual relationship where the plant serves as food and in return, the bee help them their reproduction. Animals pollinate about $75 \%$ of food crops worldwide, with bees as the world's primary pollinator. In general, bees rely on flower scents to locate blooming flowers as visual clue is limited and also their host plants from a distance. In this review, an attempt is made to collect some relevant 107 published papers from three scientific databases, Google Scholar, Scopus, and Web of Science database, covering the period from 1959 to 2021.

Results: Flowering plants are well documented to actively emit volatile organic compounds (VOCs). However, only a few of them are important for eliciting behavioral responses in bees. In this review, fifty-three volatile organic compounds belonging to different class of compounds, mainly terpenoids, benzenoids, and volatile fatty acid derivatives, is compiled here from floral scents that are responsible for eliciting behavioral responses in bees. Bees generally use honest floral signals to locate their host plants with nectar and pollen-rich flowers. Thus, honest signaling mechanism plays a key role in maintaining mutualistic plant-pollinator associations.

Conclusions: Considering the fact that floral scents are the primary attractants, understanding and identification of VOCs from floral scent in plant-pollinator networks are crucial to improve crop pollination. Interestingly, current advances in both VOCs scent gene identification and their biosynthetic pathways make it possible to manipulate particular VOCs in plant, and this eventually may lead to increase in crop productivity.

Keywords: flowering plant, pollination, bees, flower scent, honest floral signal

\section{Introduction}

Animal pollinators are responsible for aiding over $80 \%$ of the world's flowering plants to reproduce, including $75 \%$ of all crops, and about 35\% of the world's food crop (Klein et al. 2007; Potts et al. 2016). Among them, bees (Hymenoptera, Apoidea), are considered as the most important pollinator. They are characterized by their high degree of diversity, with about 20000 species worldwide (Michener 2007). Bees can be broadly grouped as either specialists or generalists depending on the diversity of floral resources they forage from. Specialist bees account 20\%-30\% bee species, collecting pollen from members of a single plant family or a genus (oligolectic) (Minckley and Roulston 2006), whereas most bees are generalist bees, which collect pollen from a broad variety of plant species belonging to various families (Cane and Sipes 2006). Honeybees, bumblebees and many mason bees, including Osmia lignaria are some of the bees that categorize under generalist (Chittka and Wells 2004; Lunau and Maier 1995).

Mutual coexistence between insects and flowering plants for over 120 million years has led to a mutual relationship where the plant serves as food and in return the insect help them with their reproduction (Bascompte 2019; Engel 2000; Poinar and Danforth 2006). Pollinators, particularly bees learn associations between floral features (scent, color, shape, texture, and other floral signals) and the reward (nectar and pollen), and use these effectively to locate their host flowering plants (Clarke et al. 2013; Muth et al. 2016; Whitney et al. 2009). For these interactions, each part has evolved differential adaption to enhance the performance (Fig. 1). Olfactory cues are often of major importance to bees to make flower choices, because olfactory cues are easily learned and remembered by pollinators (Wright and Schiestl 2009). Olfactory cues are also important when visual signal is limited, such as foraging on night-blooming 


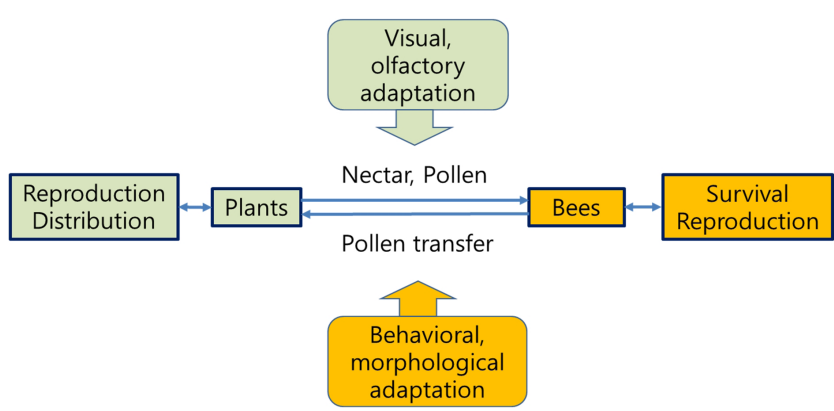

Fig. 1 Schematic diagram showing the interaction of bee-flower interaction and adaptation to enforce the interaction.

flowers and to locate their host plants from a distance ( $\mathrm{Ra}$ guso et al. 2003; Raguso and Willis 2002). In return, pollinators are equipped with behavioral and morphological adaptions to better serve the plant needs.

The notion that volatiles emitted by the plants mediate communication between plants and animals has long been acknowledged (Fraenkel 1959). The idea of volatile compounds mediation has been entertained since then by many other studies (Dötterl et al. 2014; Cheng et al. 2019; Knudsen et al. 2006). In general, flowering plants emit volatile organic compounds (VOCs), which are diverse and very complex. VOCs are lipophilic in nature, and possess high vapor pressure at ambient temperatures, as they are composed of low molecular weight. Indeed, plants belonging to 90 families have been reported to possess over 1700 individual volatile organic compounds (Knudsen et al. 2006). The composition of floral VOCs depend on many factors, including flower age, plant genotype, pollination status and others (Rodriguez-Saona et al. 2011; Klatt et al. 2013; Cheng et al. 2019). Previous studies showed that bees, especially honeybees and bumblebees, possess the capability to differentiate between individual and blends of VOCs (Laloi and Pham-Delègue 2004; Paldi et al. 2003; Wright et al. 2002).

Pollinators have a set of behavioral preferences, both innate and learned. Although naïve bees possess innate preferences for some floral signals, bees have a quick ability to learn association between volatile component(s) and food rewards (Milet-Pinheiro et al. 2013; Raguso 2008). Associative learning preference are largely beneficial for the pollinator because it has been credited to rapid floral diversification in both floral signals and floral rewards (Schiestl and Johnson 2013). Several studies over the years have indicated the importance of olfactory cues in bee-flowering plants interactions (Raguso 2008; Williams 1983). Bees possess one of the highest number of chemoreceptors (e.g., honey bees $=170$; fruit flies $=62$; mosquitoes $=79$ ) in the insect kingdom that make them superior to recognize diverse floral odors (Robertson and Wanner 2006).

VOCs produced by the plants may have a wide variety of biological activities, such as antibacterial, antifungal (Hammer et al. 2003; Huang et al. 2012) and repellent ac- tivities against florivores (Junker et al. 2011). Given the vital role of effective pollination to many important crop yields, the pollinators of such crops are also linked to their VOCs of the floral scents. To this end, in this review, we compile fifty-three VOCs that mediate between bees and their flowering plant host.

\section{Literature collection}

In this review, an attempt is made to collect all relevant papers from three scientific databases (Google Scholar, Scopus, and Web of Science database), covering the period from 1959 to 2021. The following search terms were used: "flower scent", "bee pollination"; "bee-flower scent interaction", "flower volatile composition"; "honest floral signal". Additional articles were also identified from the first search reference lists. From this search, we listed 53 VOCs compounds (Table 1) from 107 published papers.

\section{Results}

\section{Flower scents}

Bees in general pollinate a wide variety of plants that differ in floral morphology (size, shape), color, and scent. Understanding of floral scents are key in bee-plant pollination network as bees heavily rely on floral scents to locate their host plants (Endress 1996; Proctor et al. 1996). Flowers can emit a variety of odor blends, which can be learned and recognized by their visiting pollinators (Dobson 2006). Flowering plants are well recognized to actively emit specific floral scent signals to attract pollinators (Knudsen et al. 2006; Williams 1983). In this review, an attempt is made to compile fifty-three volatile organic compounds (Table 1) from floral scent that are responsible for eliciting behavioral responses in bees. These VOCs belongs to different class of compounds, mainly terpenoids, benzenoids and volatile fatty acid.

\section{Terpenoids}

Terpenoids comprise structurally diverse and the largest class of plant secondary metabolites present in all living organisms, particularly in flowering plants (Pichersky and Raguso 2018). In addition to attracting pollinators, terpenoids also play crucial role in plant's defense against herbivorous (Abbas et al. 2017). Terpenoids presented over 50000 well known naturally produced compounds across all kingdom of life (Belcher et al. 2020). Isopentenyl diphosphate and dimethylallyl diphosphate, the two building blocks for terpenoid biosynthesis, are generally synthesized via two pathways: the mevalonate pathway (Liao et al. 2016) and the 2-C-methyl-D-erythritol 4-phosphate pathway (Rohmer 1999) (Fig. 2). Terpenoids are largely biosynthesized and stored in plant tissues with specialized structures such as secretory cavities, resin canals, latex canals, 
Table 1 Some floral plant and their volatile organic compounds that elicit response in bees

\begin{tabular}{|c|c|c|c|}
\hline Volatile organic compounds & Plant source & Bee species & References \\
\hline $\begin{array}{l}\text { 2-phenylethanol }(18)^{\mathrm{B}} ; \\
\text { 4-oxoisophorone }(44)^{\mathrm{C}} ; \\
(3 E, 6 E) \text { - } \alpha \text {-farnesene }(45)^{\mathrm{T}} ; \\
(6 Z, 9 Z) \text {-heptadecadiene }(28)^{\mathrm{F}} ; \\
\text { (8Z)-heptadecene }(29)^{\mathrm{F}} ; \\
\text { Nonanal }(30)^{\mathrm{F}}\end{array}$ & $\begin{array}{l}\text { Actinidia deliciosa } \\
\text { (kiwifruit) }\end{array}$ & $\begin{array}{l}\text { Honeybees } \\
\text { (Apise mellifera) }\end{array}$ & $\begin{array}{r}\text { Tatsuka et al. 1990; } \\
\text { Twidle et al. } 2015\end{array}$ \\
\hline $\begin{array}{l}\alpha \text {-farnesene }(41)^{\mathrm{T}} ; \\
\quad p \text {-anisaldehyde }(42)^{\mathrm{B}} ; \\
\text { Acetophenone }(43)^{\mathrm{B}} ; \\
\text { Phenylacetaldehyde }(40)^{\mathrm{B}}\end{array}$ & Brassica rapa & $\begin{array}{l}\text { Bumble bee } \\
\text { (Bombus terrestris L.) }\end{array}$ & $\begin{array}{l}\text { Knauer and Schiestl } \\
2015\end{array}$ \\
\hline $\begin{array}{l}\beta \text {-ocimene }(1)^{\mathrm{T}} ; \\
(E, E) \text { - } \alpha \text {-farnesene }(45)^{\mathrm{T}} ; \\
\text { 1H-indole }(38)^{\mathrm{N}} ; \\
\text { 2-phenylethyl acetate }(12)^{\mathrm{B}} ; \\
\text { 2-phenylethanol }(18)^{\mathrm{B}} ; \\
\text { 6,10,14-trimethyl-2-pentadecanone }(31)^{\mathrm{F}} ; \\
\text { Benzaldehyde }(23)^{\mathrm{B}} ; \\
\text { Linalool }(2)^{\mathrm{T}} ; \\
\text { Phenylacetaldehyde }(40)^{\mathrm{B}}\end{array}$ & Brassica spp. & $\begin{array}{l}\text { Honeybees } \\
\text { (Apise mellifera) }\end{array}$ & Kobayashi et al. 2012 \\
\hline $\begin{array}{l}\text { 1,6-dioxaspiro[4.5] decane }(33)^{\mathrm{s}} ; \\
\text { E-7-methyl-1,6-dioxaspiro[4.5] decane }(34)^{\mathrm{s}} ; \\
\text { E-2-methyl-1,7-dioxaspiro[5.5] undecane }(35)^{\mathrm{s}} \text {; } \\
\text { E-7-ethyl-1,6-dioxaspiro[4.5] decane }(36)^{\mathrm{s}}\end{array}$ & Campanula trachelium & $\begin{array}{l}\text { Campanula-specialist bee } \\
\text { (Chelostoma rapunculi) }\end{array}$ & $\begin{array}{l}\text { Milet-Pinheiro et al. } \\
2013\end{array}$ \\
\hline $\begin{array}{l}\text { 1-octanol }(19)^{\mathrm{F}} ; \\
\text { 2-phenylethanol }(18)^{\mathrm{B}}\end{array}$ & Campomanesia phaea & $\begin{array}{l}\text { Nocturnal bees (Megalopta } \\
\text { spp.; Ptiloglossa spp.) }\end{array}$ & Cordeiro et al. 2017 \\
\hline $\begin{array}{l}p \text {-anisaldehyde }(42)^{\mathrm{B}} ; \\
\text { Benzaldehyde }(23)^{\mathrm{B}} ; \\
\text { Phenylacetaldehyde }(40)^{\mathrm{B}}\end{array}$ & $\begin{array}{l}\text { Cirsium arvense } \\
\text { (Canada thistle) }\end{array}$ & $\begin{array}{l}\text { Honeybees and } \\
\text { Lasioglossum }\end{array}$ & Theis 2006 \\
\hline 1,2,4-trimethoxybenzene $(46)^{\mathrm{B}}$ & Cucurbita spp. & $\begin{array}{l}\text { Peponapis pruinosa (North } \\
\text { American squash bee) }\end{array}$ & Andrews et al. 2007 \\
\hline $\begin{array}{l}\beta \text {-ocimene }(1)^{\mathrm{T}} ; \\
\beta \text {-pinene }(11)^{\mathrm{T}} ; \\
\text { Linalool }(2)^{\mathrm{T}}\end{array}$ & Gongora spp. & Orchid bees (Euglossini) & $\begin{array}{l}\text { Hetherington-Rauth } \\
\text { and Ramírez } 2016\end{array}$ \\
\hline p-methoxyanisole $(24)^{\mathrm{B}}$ & $\begin{array}{l}\text { Hydrocleys martii } \\
\text { (aquatic plants) }\end{array}$ & $\begin{array}{l}\text { Oligolectic bees } \\
\text { (Protodiscelis palpalis) }\end{array}$ & Carvalho et al. 2014 \\
\hline Benzyl acetate $(13)^{\mathrm{B}}$ & Masdevallia lehmannii & Euglossine bees & $\begin{array}{l}\text { Gerlach and Schill } \\
1991\end{array}$ \\
\hline $\begin{array}{l}\text { 2-tridecanone }(25)^{\mathrm{F}} ; \\
\text { Diacetin }(27)^{\mathrm{G}} ; \\
\text { Heptanoic acid }(26)^{\mathrm{F}}\end{array}$ & Lysimachia spp. & $\begin{array}{l}\text { Macropis fulvipes } \\
\text { (Oil-collecting bees) }\end{array}$ & Schäffler et al. 2015 \\
\hline $\begin{array}{l}\text { cis-3-hexenyl acetate }(32)^{\mathrm{F}} ; \\
\text { Linalool }(2)^{\mathrm{T}} ; \\
\text { Methyl salicylate }(16)^{\mathrm{B}} ;\end{array}$ & $\begin{array}{l}\text { Medicago sativa } \\
\text { (alfalfa) }\end{array}$ & $\begin{array}{l}\text { Honeybees } \\
\text { (Apise mellifera) }\end{array}$ & $\begin{array}{l}\text { Henning and Teuber } \\
1992\end{array}$ \\
\hline $\begin{array}{l}E, E \text {-farnesol }(3)^{\mathrm{T}} ; \\
\text { E,E-farnesyl hexanoate }(9)^{\mathrm{T}} ; \\
\text { Nonanoic acid }(10)^{\mathrm{T}}\end{array}$ & $\begin{array}{l}\text { Ophrys sphegodes } \\
\text { (spider-orchid) }\end{array}$ & $\begin{array}{l}\text { Solitary bee } \\
\text { (Andrena nigroaenea) }\end{array}$ & $\begin{array}{l}\text { Ayasse et al. 2000; } \\
\text { Schiestl and Ayasse } \\
2001\end{array}$ \\
\hline $\begin{array}{l}\beta \text {-ocimene }(1)^{\mathrm{T}} \\
\text { Linalool }(2)^{\mathrm{T}}\end{array}$ & $\begin{array}{l}\text { Paullinia cupana } \\
\text { (guarana) }\end{array}$ & $\begin{array}{l}\text { Nocturnal bee } \\
\text { (Megalopta spp.) }\end{array}$ & Krug et al. 2018 \\
\hline Protoanemonin $(39)^{\mathrm{L}}$ & Ranunculus spp. & Chelostoma bees & $\begin{array}{l}\text { Dobson and } \\
\text { Bergström } 2000\end{array}$ \\
\hline $\begin{array}{l}\beta \text {-ocimene }(1)^{\mathrm{T}} ; \\
\text { 2-phenylethyl acetate }(12)^{\mathrm{B}} ; \\
\text { 2-phenylethanol }(18)^{\mathrm{B}} ; \\
\text { Methyl 2-methoxybenzoate }(47)^{\mathrm{B}} ; \\
\text { Methyl 4-methoxybenzoate }(48)^{\mathrm{B}} ; \\
\text { Methyl nicotinate }(38)^{\mathrm{N}}\end{array}$ & $\begin{array}{l}\text { Raphanus sativus } \\
\text { (radish) }\end{array}$ & $\begin{array}{l}\text { Honeybees } \\
\text { (Apise mellifera) }\end{array}$ & Kobayashi et al. 2012 \\
\hline 1,4-dimethoxybenzene $(24)^{\mathrm{B}}$ & Salix spp. & $\begin{array}{l}\text { Oligolectic bee } \\
\text { (Andrena vaga) }\end{array}$ & $\begin{array}{l}\text { Tollsten and Knudsen } \\
\text { 1992; Dötterl et al. } \\
2005\end{array}$ \\
\hline
\end{tabular}


Table 1 Continued

\begin{tabular}{|c|c|c|c|}
\hline Volatile organic compounds & Plant source & Bee species & References \\
\hline $\begin{array}{l}\beta \text {-pinene }(11)^{\mathrm{T}} ; \\
\quad \text { Limonene }(49)^{\mathrm{T}}\end{array}$ & Salvia spp. & $\begin{array}{l}\text { Lasioglossum spp.; } \\
\text { Xylocopa violacea }\end{array}$ & Giuliani et al. 2020 \\
\hline $\begin{array}{l}\text { 1,8-cineole }(20)^{\mathrm{T}} ; \\
\text { 2-phenylethyl acetate }(12)^{\mathrm{B}} ; \\
\text { Benzyl acetate }(13)^{\mathrm{B}} ; \\
\text { p-cresol }(50)^{\mathrm{B}} ; \\
\text { p-cresyl acetate }(51)^{\mathrm{B}} ; \\
\text { Methyl benzoate }(14)^{\mathrm{B}} ; \\
\text { Methyl cinnamate }(15)^{\mathrm{B}} ; \\
\text { Methyl salicylate }(16)^{\mathrm{B}} ; \\
\text { Vanillin }(17)^{\mathrm{B}}\end{array}$ & Stanhopeinae spp. & Orchid bees (Euglossini) & $\begin{array}{l}\text { Williams and Whitten } \\
1983\end{array}$ \\
\hline Anethole $(52)^{\mathrm{B}}$ & Synthetic compounds & $\begin{array}{l}\text { Honeybees } \\
\text { (Apise mellifera) }\end{array}$ & $\begin{array}{l}\text { Allsopp and Cherry } \\
1991\end{array}$ \\
\hline $\begin{array}{l}\text { Benzyl acetate }(13)^{\mathrm{B}} ; \\
\text { Eucalyptol }(20)^{\mathrm{T}} ; \\
\text { Eugenol }(21)^{\mathrm{B}} ; \\
\text { Methyl salicylate }(16)^{\mathrm{B}} ; \\
\text { Skatole }(22)^{\mathrm{B}} ; \\
\text { Vanillin }(17)^{\mathrm{B}}\end{array}$ & Synthetic compounds & $\begin{array}{l}\text { Nocturnal bee } \\
\text { (Megalopta aegis; } \\
\text { Megalopta amoena; } \\
\text { Megalopta guimaraesi) }\end{array}$ & Knoll and Santos 2012 \\
\hline $\begin{array}{l}(E, E) \text {-farnesol }(3)^{\mathrm{T}} ; \\
(Z) \text {-citral }(4)^{\mathrm{T}} ; \\
\text { Geranic acid }(5)^{\mathrm{T}} ; \\
\text { Geraniol }(6)^{\mathrm{T}} ; \\
\text { Nerol }(7)^{\mathrm{T}} ; \\
\text { Nerolic acid }(8)^{\mathrm{T}}\end{array}$ & Synthetic compounds & $\begin{array}{l}\text { Honeybees } \\
\text { (Apise mellifera) }\end{array}$ & Williams et al. 1981 \\
\hline
\end{tabular}

Structure numberings are in parenthesis. Class of compounds are also represented by letter in superscript: B, benzenoids; C, cyclohexenones; F, volatile fatty acid derivatives; L, lactone; $N$, nitrogen containing compounds; $S$, spiroacetals; $T$, terpenoids

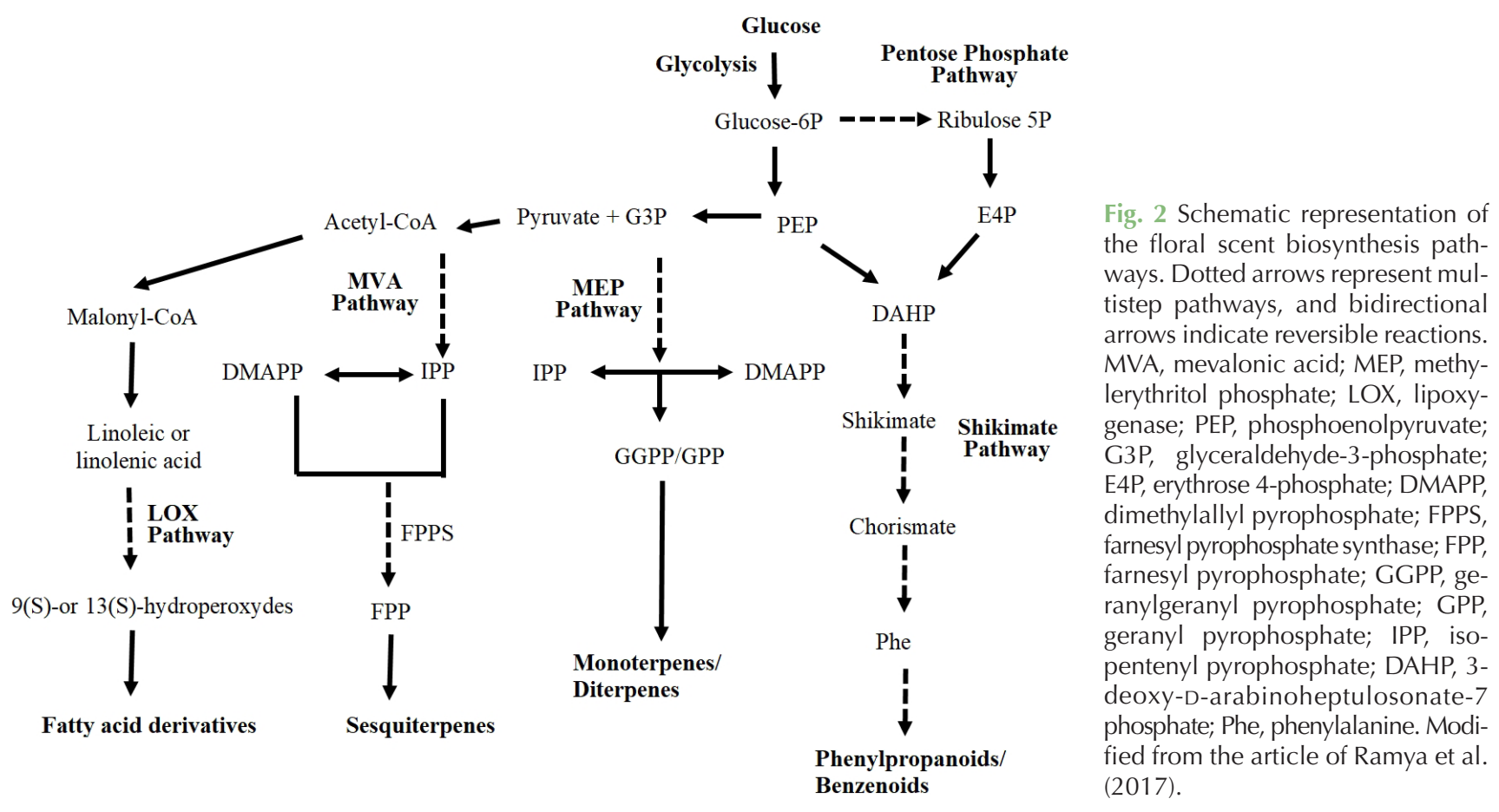

glandular trichomes (Holopainen et al. 2013).

Floral scents of many flowering species are dominated by terpenoids (Fig. 3), which are known to attract generalist bees, including in Chamaedora linearis (Knudsen et al. 2001), Ranunculus acris (Bergström et al. 1995) and Rubus

idaeus (Robertson et al. 1995). Among the terpenoids, trans- $\beta$-ocimene (1) is the most crucial VOC that serves as a general pollinator attractant (Farré-Armengol et al. 2017). It was also noted that $47.5 \%$ of the 291 plant species investigated was found to possess trans- $\beta$-ocimene (Farré-Ar- 
<smiles>C=C/C(C)=C/C=C(C)C</smiles>

(1)<smiles>C=CC(C)(O)CCC=C(C)C</smiles>

(2)<smiles>CC(C)=CCC/C(C)=C/CC/C(C)=C/CO</smiles>

(3)<smiles>CC(C)=CCCC(C)=CC=O</smiles>

(4)<smiles>CC(C)=CCC/C(C)=C/C(=O)O</smiles>

(5)<smiles>CC(C)=CCCC(C)=CCO</smiles>

(6)

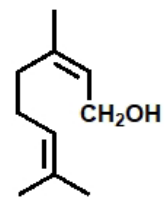

(7)<smiles>CC(C)=CCC/C(C)=C\C(=O)O</smiles>

(8)<smiles>CCCCCC(=O)OC/C=C(\C)CC/C=C(\C)CCC=C(C)C</smiles>

(9)

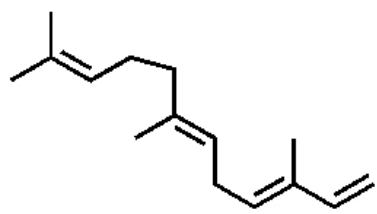

(41)<smiles>C=C/C(C)=C/C/C=C(\C)CCC=C(C)C</smiles>

(45)

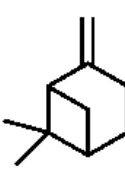

(11)

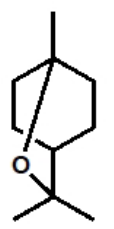

(20)
Fig. 3 Some of the commonest terpenoids from flower scents that trigger response in bees. mengol et al. 2017). Both trans- $\beta$-ocimene (1) and linalool (2), which were among the most prevalent terpenoids produced by flowering plants, are linked to pollinator attractions, such as honeybees (Kobayashi et al. 2012), Euglossini bees (Hetherington-Rauth and Ramírez 2016), Nocturnal bees (Megalopta spp.) (Krug et al. 2018). Williams et al. (1981) demonstrated that each of the seven components of the Nasonov secretion ((E,E)-farnesol (3), (Z)-citral (4), geranic acid (5), geraniol (6), nerol (7) and nerolic acid (8)) attracted foraging honeybees individually, though their level of attraction varied. These compounds (3-8) are also among the most common compounds produced by plants.

Orchids of the genus Ophrys are well understood to employ sexual deception by emitting a chemical composition identical to that of female sex pheromones, and so males are deceived into attempting to mate with the flowers (Ayasse et al. 2000). Orchids are mostly pollinated by the male solitary bee Andrena nigroaenea, which are lured to the orchid by visual cues and volatile semiochemicals (Borg-Karlson 1990; Borg-Karlson and Tengö 1986). It was also noted that $(E, E)$-farnesyl hexanoate $(9),(E, E)$-farnesol (3) and nonanoic (10) acid from Ophrys sphegodes trig- gered antennae's response of males receptor (Ayasse et al. 2000). After pollination, it is interesting to note that $O$. sphegodes (also known as spider-orchid) marks itself with (E,E)-farnesyl hexanoate (9) to prevent the solitary bee Andrena nigroaenea from having duplicate visits (Schiestl and Ayasse 2001). Gongora spp. are common in angiosperm families and emit many diverse and complex VOCs. Among the many VOCs, $\beta$-ocimene (1), linalool (2) and $\beta$-pinene (11) are linked with the attraction of generalist pollinators including bees, flies and butterflies (Dobson 2006; Giuliani et al. 2020).

Terpenoids are highly diverse in nature because a single terpenoid is susceptible to undergo several reactions (e.g., carbocation cyclization, rearrangement, and elimination reactions), lead to multiple products (Christianson 2018; Karunanithi and Zerbe 2019). It has been also demonstrated that the occurrence of multi-substrate terpenoids depend on the physiological and development status of plants. This suggests that terpene/terpenoids may be the plant's preference in response to fluctuations in the environment (Pazouki and Niinemets 2016). 


\section{Benzenoid compounds}

Benzenoids, also known as phenylpropanoids, constitute the second largest class of plant VOCs (Knudsen et al. 2006). They are exclusively derived from the aromatic amino acid phenylalanine, which is synthesized via the shikimate/phenylalanine biosynthetic pathways (Yoo et al. 2013). Benzenoids are biosynthesized via the shikimate pathway, involving a sequence of seven metabolic steps beginning with the condensation of phosphoenolpyruvate and erythrose 4-phosphate to form chorismate, the precursor of the aromatic amino acids and many aromatic secondary metabolites (Fig. 2) (Peled-Zehavi et al. 2015; Tzin and Galili 2010).

Male bees in Euglossini widely pollinate flower species belonging primarily to the Orchidaceae family (Endress 1996). Among the common VOCs that eliciting response in euglossine bees were benzenoids (Fig. 4) from Stanho-<smiles>CC(=O)OCCc1ccccc1</smiles>

(12)<smiles>COC(=O)c1ccccc1O</smiles>

(16)<smiles>O=Cc1ccccc1</smiles>

(23)<smiles>CC(=O)c1ccccc1</smiles>

(43)<smiles>Cc1ccc(O)cc1</smiles>

(50)<smiles>CC(=O)OCc1ccccc1</smiles>

(13)<smiles>COc1cc(C=O)ccc1O</smiles>

(17)<smiles>COc1ccc(OC)cc1</smiles>

(24)<smiles>COc1ccc(OC)c(OC)c1</smiles>

(46)<smiles>CC(=O)Oc1ccc(C)cc1</smiles>

(51)<smiles>COC(=O)c1ccccc1</smiles>

(14)<smiles>OCCc1ccccc1</smiles>

(18)<smiles>O=CCc1ccccc1</smiles>

(40)<smiles>COC(=O)c1ccccc1OC</smiles>

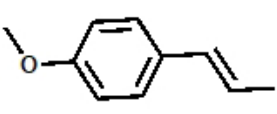

(52) peinae spp., such as 2-phenylethyl acetate (12), benzyl acetate (13), methyl benzoate (14), methyl cinnamate (15), methyl salicylate (16) and vanillin (17) (Andrews et al. 2007; Williams and Whitten 1983). Floral scents may be particularly effective in two scenarios-for plants pollinated at night when the floral resources are less visible and attraction from a distance (Krug et al. 2018). Bees are largely light sensitive and limited light levels or anything that obscure of visual cues can easily affect their foraging flights (Galen et al. 2019; Kelber et al. 2006) except nocturnal bees (Hopkins et al. 2000; Wcislo and Tierney 2009). For instance, a benzenoid (2-phenylethanol (18)) along with 1-octanol (19) emitted by a night flowering plant Campomanesia phaea (flowering period from 04:30 to 05:00 am) attracted night-active nocturnal bees (Megalopta and Ptiloglossa species) (Cordeiro et al. 2017). Moreover, benzyl acetate (13), eucalyptol (20), eugenol (21), methyl salicylate<smiles>COC(=O)/C=C/c1ccccc1</smiles>

(15)<smiles>C=CCc1ccc(O)c(OC)c1</smiles>

(21)<smiles>COc1ccc(C=O)cc1</smiles>

(42)<smiles>COC(=O)c1ccc(OC)cc1</smiles>

(48)<smiles>OCc1ccccc1</smiles>

(53)
Fig. 4 Benzenoids from flower scents that elicit response in bees. 
(16), skatole (22) and vanillin (17) also lured nocturnal bees, Megalopta bees (Knoll and Santos 2012; Krug et al. 2018; Wcislo and Tierney 2009). Indeed, benzaldehyde (23) and 2-phenylethanol (18) are the two predominant benzenoids of floral scents of many species (Farré-Armengol et al. 2017; Theis 2006).

Many different oligolectic bee species are usually attracted to the flowering species belonging to the genus Salix because of its pollen are easily accessible (Michener 2000; Newsholme 1992). 1,4-Dimethoxybenzene (24) emitted by Salix spp. are responsible for the attraction of the oligolectic bee Andrena vaga (Dötterl et al. 2005; Tollsten and Knudsen 1992). 1,4-Dimethoxybenzene (24) was also produced by the tiny flowers of Notylia spp. to attract the male euglossine bees (Gerlach and Schill 1991). It was reported that $p$-methoxyanisole, also known as 1,4-dimethoxybenzene (24) from Hydrocleys martii (aquatic plant) lure Oligolectic bees Protodiscelis palpalis (Carvalho et al. 2014). Synthetic compounds, such as anethole (52), also play crucial role in attracting honeybees (Allsopp and Cherry 1991).

\section{Volatile fatty acid derivatives}

Fatty acid derivatives are the third largest class of flower VOCs (Fig. 5), which derive from the unsaturated C18 fatty acids (linolenic and linoleic) (Muhlemann et al. 2014). Vol- atile fatty acids are synthesized and relied on a plastidic pool of acetyl-CoA derived from pyruvate, the final product of glycolysis (Feussner and Wasternack 2002).

Most of the oil-producing flowers and their frequent visitors (flower-oil-collecting bees) are neotropical. Oil-collecting bee species, such as Macropis bees were frequently noticed to collect oil and pollen only from Lysimachia spp. as food for their larvae (Dötterl and Schäffler 2007). Interestingly, fatty acid derivatives (such as 2-tridecanone (25) and heptanoic acid (26) and glycerol derivative (diacetin (27)) from Lysimachia spp. are responsible for enticing Macropis bees (Schäffler et al. 2015).

Several previous studies also demonstrated that volatile fatty acid derivatives such as $(6 Z, 9 Z)$-heptadecadiene (28), (8Z)-heptadecene (29) and nonanal (30) (Actinidia deliciosa; [Tatsuka et al. 1990; Twidle et al. 2015]), 6,10,14trimethyl-2-pentadecanone (31) (Brassica spp.; [Kobayashi et al. 2012]), cis-3-hexenyl acetate (32) (Medicago sativa; [Henning and Teuber 1992]) are capable of attracting honeybees.

\section{Rare volatile organic compounds}

Flowering plants are known to emit wide range of VOCs from being relatively rare to common. In general, specialized pollinators are attracted to flowering plants emitting

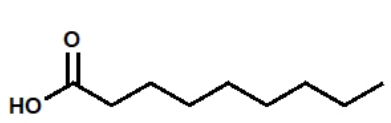

(10)

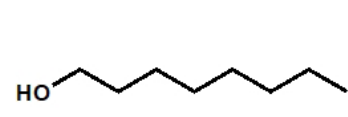

(19)

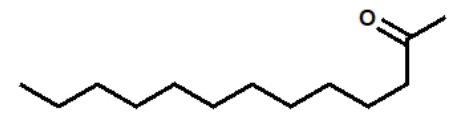

(25)

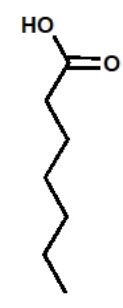

(26)

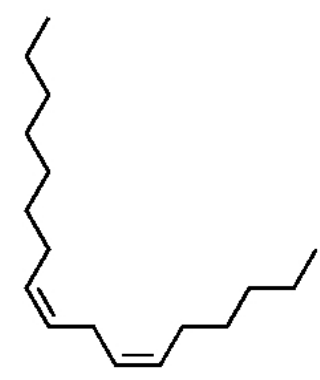

(28)

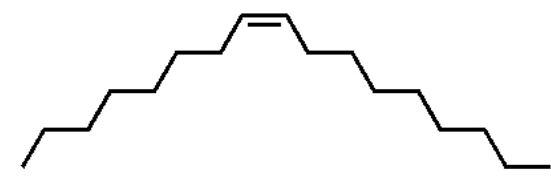

(29)

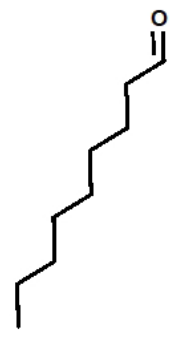

(30)

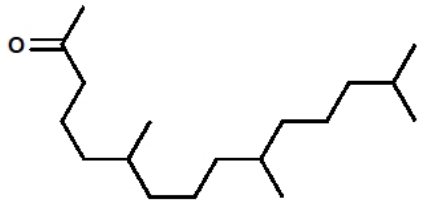

(31)<smiles>CC/C=C\CCOC(C)=O</smiles>

(32)
Fig. 5 Volatile fatty acid derivatives from flower scents that elicit response in bees. 
rare VOCs (Fig. 6). One good example is Campanula trachelium, a flowering plant, which emits spiroacetal volatile compounds (33-36) to attract Campanula-specialist bee (Milet-Pinheiro et al. 2013). Likewise, $N$-containing compounds such as methyl nicotinate (37) (Raphanus sativus) and $1 \mathrm{H}$-indole (38) (Brassica spp.) were also reported to have positive responses to honey bee's antenna (Kobayashi et al. 2012). Diacetin (27) (a volatile acetylated glycerol) from Lysimachia sp. was also found to be a crucial signal in the Lysimachia-Macropis pollination system by eliciting strong antennal responses in oil-collecting bees (Macropis bee) (Schäffler et al. 2015).

Mostly hydrocarbons produced by Ophrys flowers are active in triggering behavioral response in the male pollinators (mostly the solitary bee Andrenidae) (Ayasse et al. 2000; Borg-Karlson 1990; Kullenberg 1973; Paulus and Gack 1990). The newly-emerged of solitary bee Chelostoma florisomne is enticed by the pollen of Ranunculus sp., which emits a rare lactone of $\gamma$-hydroxyvinylacrylic acid, protoanemonin (39) (Dobson and Bergström 2000). In addition to bee attractant, protoanemonin (39) was also reported to possess antifungal activity (Martín et al. 1990).

\section{Honest flower signals}

In plant-pollinator relationship, pollinators prefer to visit flowering plants with honest floral signals that correlate positively with the reward status (food amount) (Bolstad et al. 2010). Honest signals could be either olfactory, visual, size, shape or any floral signal of the flower. In fact, pollinators are mostly guided to their host flowering plants by innate preferences or their ability to learn association between VOCs and food rewards (Arenas and Farina 2012; Raguso 2008).

There are several cases where bees make their decision to visit flowers based on the amount of the volatile components released by the flowers, and their association with the reward (Dobson et al. 1999; Dötterl and Jürgens 2005; Mena Granero et al. 2005). For example, level of phenylacetaldehyde (40) in Brassica rapa is associated with the number of visitation by the bumble bee (Bombus terrestris) (Knauer and Schiestl 2015). Similarly, the level of diacetin (27) in Lysimachia sp. is linked to the number of visitation by the oil-collecting bees (Macropis bee) (Schäffler et al. 2015). Other floral signals can also serve as honest signal, such as coloured nectar (Hansen et al. 2007) and the size of the gland secreting reward in Dalechampia schottii (Bolstad et al. 2010). Synthetic phenylacetaldehyde appeared to attract large numbers of bees in a trap that aimed at capturing moths (Meagher 2002). In general, pollinators naturally prefer to navigate flowers with high level of honest floral VOC signals (Majetic et al. 2009; Parachnowitsch et al. 2012), indicating that pollination services can be elevated by producing more honest flower scent signal. For instance, four VOCs ( $\alpha$-farnesene (41), $p$-anisaldehyde (42), acetophenone (43), phenylacetaldehyde (40)) emitted by Brassica rapa L. are well documented to lure bumblebees for pollination (Knauer and Schiestl 2015). However, phenylacetaldehyde (40) only serves as an honest signal by associating high amount of this compound with their corresponding proportions of pollen and nectar. In another<smiles>Cc1c[nH]c2ccccc12</smiles>

(22)

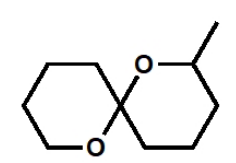

(35)<smiles>C=C1C=CC(=O)O1</smiles><smiles>CCC1CCCC2(CCCO2)O1</smiles>

(36)<smiles>CC1=CC(=O)CC(C)(C)C1=O</smiles>

(44)

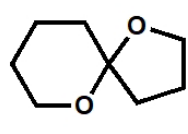

(33)

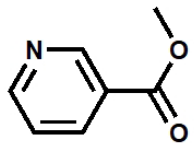

(37)

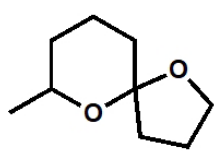

(34)

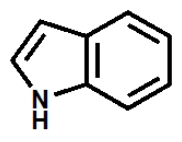

(38)
Fig. 6 Compounds belonging cyclohexanone, lactone, N-containing compounds and spiroacetals from flower scents that trigger response in bees. 
example, $(E, E)$-farnesol (3) alone and a mixture of citral (4) and (E,E)-farnesol (3) from Ophrys lutea were found to be highly attractive and elicited a few long-lasting behavioral events to many Andrena species (Borg-Karlson and Tengö 1986).

Nectar-depleted flowers can also emit distinct volatiles to repel pollinators and non-pollinator herbivores (Galen et al. 2011). The Orchid Ophrys sphegodes emits $(E, E)-$ farnesyl hexanoate (9) to avoid the solitary bee Andrena nigroaenea from having mutliple visits (Schiestl and Ayasse 2001). Therefore, flowers regulate their emission of attractant and repellent chemicals to maintain a balance between nectar supply and demand.

In fact, flowering plants are rich with secondary metabolites. Terpenoids (such as trans- $\beta$-ocimene (1), linalool (2), limonene (49)) and benzenoids benzaldehyde (23), benzyl alcohol (53) and 2-phenylethanol (18) have been reported to occur in floral scent in more than half of the families of seed plants (Cseke et al. 2007; Knudsen et al. 2006). These compounds mostly serve as attractants to generalist bees. In a study conducted by (Henning and Teuber 1992) indicated that linalool (2), methyl salicylate (16), and cis-3-hexenyl acetate (32) from Medicago sativa L. (alfalfa) elicited a strong honeybee antennal response. Linalool (2) and methyl salicylate (16) appeared to increase honeybees' visitation to alfalfa. In contrast to linalool (2) and methyl salicylate (16), cis-3-hexenyl acetate (32) had the opposite effects. Thus, it was suggested that alfalfa yields could be increased through genetic manipulation by selection of alfalfa variety rich with linalool and methyl salicylate, but not cis-3-hexenyl acetate (32) (Henning and Teuber 1992).

Over the years, several attempts have been made to modulate plant VOCs profiles and their effect on insect behavior. Numerous strategies have been implemented, such as by the modification of existing pathways, or by blocking the competing pathways or by introducing new gene(s) (Lange and Ahkami 2013). One success story of the strategy is that plant defense mechanism was highly improved by producing the volatile patchoulol along with additional sesquiterpene products in transgenic tobacco, overexpressing Pogostemon cablin patchoulol synthase (Wu et al. 2006).

\section{Conclusions}

Floral scents are composed of hundreds of diverse and complex volatile molecules. Understanding the function of these floral scent alone (Pichersky and Raguso 2018) or in synergy with other floral signals (e.g., visual cues) (Kunze and Gumbert 2001; Raguso and Willis 2002) is crucial in plant-pollinator mediations. Flowers generally use honest floral signals, and bees are able to correlate floral signals with nectar and pollen-rich flowers (Howell and Alarcón
2007). Thus, honest signaling mechanism plays a key role in maintaining mutualistic plant-pollinator associations (Knauer and Schiestl 2015). It was also indicated by previous studies that flowers with high level of floral VOCs can improve pollination service (Majetic et al. 2009; Parachnowitsch et al. 2012). For instance, field trials with flower scent manipulation to increase honeybee's visitation to kiwifruit flowers led to some success (Pinzauti 1990; Tsirakoglou et al. 1997). Thus, crop production may be improved through genetic manipulation of the floral scent (Henning and Teuber 1992; Kobayashi et al. 2012; Twidle et al. 2015).

Given the role of chemical communication in plant-pollinator interactions, understanding and identification of VOCs from floral scent are crucial in improving crop pollination. Interestingly, current advances in both VOCs scent gene identification and their biosynthetic pathways make it possible to manipulate particular VOCs in plant. Thus, this eventually may lead to increase in crop productivity.

\section{Abbreviations}

DAHP: 3-Deoxy-D-arabinoheptulosonate-7 phosphate

DMAPP: Dimethylallyl pyrophosphate

E4P: Erythrose 4-phosphate

FPPS: Farnesyl pyrophosphate synthase

FPP: Farnesyl pyrophosphate

G3P: Glyceraldehyde-3-phosphate

GGPP: Geranylgeranyl pyrophosphate

GPP: Geranyl pyrophosphate

IPP: Isopentenyl pyrophosphate

LOX: Lipoxygenase

MEP: Methylerythritol phosphate

MVA: Mevalonic acid

PEP: Phosphoenolpyruvate

Phe: Phenylalanine

VOCs: Volatile organic compounds

\section{Acknowledgements}

DB and CJ are deeply grateful to Insect ecology lab in Andong National University, South Korea.

\section{Authors' contributions}

DB reviewed and wrote the manuscript. CJ designed, analyzed and edited the manuscript. All the authors approved the manuscript.

\section{Funding}

This study was funded by the BSRP through the National Research Foundation of Korea (NRF), Ministry of Education; Grant number NRF-2018R1A6A1A 03024862.

\section{Availability of data and materials}

All data reviewed in this study are available from the corresponding author on request. 
Ethics approval and consent to participate Not applicable.

\section{Consent for publication}

Not applicable.

\section{Competing interests}

The authors declare that they have no competing interests.

\section{References}

Abbas F, Ke Y, Yu R, Yue Y, Amanullah S, Jahangir MM, et al. Volatile terpenoids: multiple functions, biosynthesis, modulation and manipulation by genetic engineering. Planta. 2017;246(5):803-16. https:// doi.org/10.1007/s00425-017-2749-x.

Allsopp PG, Cherry RH. Attraction of Apis mellifera L. (Hymenoptera: Apidae) to volatile compounds. Aust J Entomol. 1991;30(3):219-20. https://doi.org/10.1111/j.1440-6055.1991.tb00416.x.

Andrews ES, Theis N, Adler LS. Pollinator and herbivore attraction to cucurbita floral volatiles. J Chem Ecol. 2007;33(9):1682-91. https:// doi.org/10.1007/s10886-007-9337-7.

Arenas A, Farina WM. Learned olfactory cues affect pollen-foraging preferences in honeybees, Apis mellifera. Anim Behav. 2012;83(4): 1023-33. https://doi.org/10.1016/j.anbehav.2012.01.026.

Ayasse M, Schiestl FP, Paulus HF, Löfstedt C, Hansson B, Ibarra F, et al. Evolution of reproductive strategies in the sexually deceptive orchid Ophrys sphegodes: how does flower-specific variation of odor signals influence reproductive success? Evolution. 2000;54(6):19952006. https://doi.org/10.1111/j.0014-3820.2000.tb01243.x.

Bascompte J. Mutualism and biodiversity. Curr Biol. 2019;29(11):R46770. https://doi.org/10.1016/j.cub.2019.03.062.

Belcher MS, Mahinthakumar J, Keasling JD. New frontiers: harnessing pivotal advances in microbial engineering for the biosynthesis of plant-derived terpenoids. Curr Opin Biotechnol. 2020;65:88-93. https://doi.org/10.1016/j.copbio.2020.02.001

Bergström G, Dobson HE, Groth I. Spatial fragrance patterns within the flowers of Ranunculus acris (Ranunculaceae). Plant Syst Evol. 1995;195(3):221-42. https://doi.org/10.1007/BF00989298.

Bolstad GH, Armbruster WS, Pélabon C, Pérez-Barrales R, Hansen TF. Direct selection at the blossom level on floral reward by pollinators in a natural population of Dalechampia schottii: full-disclosure honesty? New Phytol. 2010;188(2):370-84. https://doi.org/10.1111/j. 1469-8137.2010.03429.x.

Borg-Karlson AK, Tengö J. Odor mimetism?: Key substances in Ophrys lutea-Andrena pollination relationship (Orchidaceae: Andrenidae). J Chem Ecol. 1986;12(9):1927-41. https://doi.org/10.1007/BF01041856.

Borg-Karlson AK. Chemical and ethological studies of pollination in the genus Ophrys (orchidaceae). Phytochemistry. 1990;29(5):1359-87. https://doi.org/10.1016/0031-9422(90)80086-V.

Cane JH, Sipes S. Characterizing floral specialization by bees: analytical methods and a revised lexicon for oligolecty. In: Ollerton J, Waser NM, editors. Plant-pollinator interactions: from specialization to generalization. Chicago: University of Chicago Press; 2006. p. 99-
122.

Carvalho AT, Dötterl S, Schlindwein C. An aromatic volatile attracts oligolectic bee pollinators in an interdependent bee-plant relationship. J Chem Ecol. 2014;40(10):1126-34. https://doi.org/10.1007/s10886014-0510-5.

Cheng Y, Zhang Z, Jia Y, Chen L, Yu H. Odour composition variation at different stages of Ficus hispida inflorescence and the attraction to pollinators. J Trop Subtrop Bot. 2019;27(3):299-308.

Chittka L, Wells H. Color vision in bees: mechanisms, ecology and evolution. In: Prete FR, editor. Complex worlds from simpler nervous systems. Cambridge: MIT Press; 2004. p. 165-91.

Christianson DW. Correction to structural and chemical biology of terpenoid cyclases. Chem Rev. 2018;118(24):11795. https://doi. org/10.1021/acs.chemrev.8b00682.

Clarke D, Whitney H, Sutton G, Robert D. Detection and learning of floral electric fields by bumblebees. Science. 2013;340(6128):66-9. https://doi.org/10.1126/science.1230883.

Cordeiro GD, Pinheiro M, Dötterl S, Alves-Dos-Santos I. Pollination of Campomanesia phaea (Myrtaceae) by night-active bees: a new nocturnal pollination system mediated by floral scent. Plant Biol (Stuttg). 2017;19(2):132-9. https://doi.org/10.1111/plb.12520.

Cseke LJ, Kaufman PB, Kirakosyan A. The biology of essential oils in the pollination of flowers. Nat Prod Commun. 2007;2(12):1317-36. https://doi.org/10.1177/1934578X0700201225.

Dobson HE, Bergström G. The ecology and evolution of pollen odors. Plant Syst Evol. 2000;222(1-4):63-87. https://doi.org/10.1007/ BF00984096.

Dobson HE, Danielson EM, Wesep IDV. Pollen odor chemicals as modulators of bumble bee foraging on Rosa rugosa Thunb. (Rosaceae). Plant Species Biol. 1999;14(2):153-66. https://doi.org/10.1046/ j.1442-1984.1999.00020.x.

Dobson HE. Relationship between floral fragrance composition and type of pollinator. In: Dudareva N, Pichersky E, editors. Biology of floral scent. Boca Raton: CRC Press; 2006. p. 147-98. https://doi. org/10.1201/9781420004007.

Dötterl S, Füssel U, Jürgens A, Aas G. 1,4-Dimethoxybenzene, a floral scent compound in willows that attracts an oligolectic bee. J Chem Ecol. 2005;31(12):2993-8. https://doi.org/10.1007/s10886-005-9152$\mathrm{y}$.

Dötterl S, Glück U, Jürgens A, Woodring J, Aas G. Floral reward, advertisement and attractiveness to honey bees in dioecious Salix caprea. PLoS One. 2014;9(3):e93421. https://doi.org/10.1371/journal. pone. 0093421 .

Dötterl S, Jürgens A. Spatial fragrance patterns in flowers of Silene latifolia: lilac compounds as olfactory nectar guides? Plant Syst Evol. 2005;255(1):99-109. https://doi.org/10.1007/s00606-005-0344-2.

Dötterl S, Schäffler I. Flower scent of floral oil-producing Lysimachia punctata as attractant for the oil-bee Macropis fulvipes. J Chem Ecol. 2007;33(2):441-5. https://doi.org/10.1007/s10886-006-9237-2.

Endress PK. Diversity and evolutionary biology of tropical flowers. Cambridge: Cambridge University Press; 1996.

Engel MS. A new interpretation of the oldest fossil bee (Hymenoptera, Apidae). Am Mus Novit. 2000;3296:1-11.

Farré-Armengol G, Filella I, Llusià J, Peñuelas J. $\beta$-ocimene, a key floral 
and foliar volatile involved in multiple interactions between plants and other organisms. Molecules. 2017;22(7):1148. https://doi. org/10.3390/molecules22071148.

Feussner I, Wasternack C. The lipoxygenase pathway. Annu Rev Plant Biol. 2002;53(1):275-97. https://doi.org/10.1146/annurev.arplant. 53.100301 .135248 .

Fraenkel GS. The raison d'ětre of secondary plant substances; these odd chemicals arose as a means of protecting plants from insects and now guide insects to food. Science. 1959;129(3361):1466-70. https://doi. org/10.1126/science.129.3361.1466.

Galen C, Kaczorowski R, Todd SL, Geib J, Raguso RA. Dosage-dependent impacts of a floral volatile compound on pollinators, larcenists, and the potential for floral evolution in the alpine skypilot Polemonium viscosum. Am Nat. 2011;177(2):258-72. https://doi.org/10.1086/ 657993.

Galen C, Miller Z, Lynn A, Axe M, Holden S, Storks L, et al. Pollination on the dark side: acoustic monitoring reveals impacts of a total solar eclipse on flight behavior and activity schedule of foraging bees. Ann Entomol Soc Am. 2019;112(1):20-6. https://doi.org/10.1093/aesa/ say035.

Gerlach G, Schill R. Composition of orchid scents attracting euglossine bees. Bot Acta. 1991;104(5):379-84. https://doi.org/10.1111/j.14388677.1991.tb00245.x.

Giuliani C, Giovanetti M, Lupi D, Mesiano MP, Barilli R, Ascrizzi R, et al. Tools to tie: flower characteristics, VOC emission profile, and glandular trichomes of two Mexican Salvia species to attract bees. Plants (Basel). 2020;9(12):1645. https://doi.org/10.3390/plants9121645.

Hammer KA, Carson CF, Riley TV. Antifungal activity of the components of Melaleuca alternifolia (tea tree) oil. J Appl Microbiol. 2003;95(4):853-60. https://doi.org/10.1046/j.1365-2672.2003.02059. $\mathrm{x}$.

Hansen DM, Olesen JM, Mione T, Johnson SD, Müller CB. Coloured nectar: distribution, ecology, and evolution of an enigmatic floral trait. Biol Rev Camb Philos Soc. 2007;82(1):83-111. https://doi. org/10.1111/j.1469-185X.2006.00005.x.

Henning JA, Teuber LR. Cornbined gas chromatography-electroantennogram characterization of alfalfa floral volatiles recognized by honey bees (Hymenoptera: Apidae). J Econ Entomol. 1992;85(1):226-32. https://doi.org/10.1093/jee/85.1.226.

Hetherington-Rauth MC, Ramírez SR. Evolution and diversity of floral scent chemistry in the euglossine bee-pollinated orchid genus Gongora. Ann Bot. 2016;118(1):135-48. https://doi.org/10.1093/aob/ mow072.

Holopainen JK, Himanen SJ, Yuan J, Chen F, Stewart CN. Ecological functions of terpenoids in changing climates. In: Ramawat KG, Mérillon JM, editors. Natural products. Heidelberg: Springer; 2013. p. 2913-40. https://doi.org/10.1007/978-3-642-22144-6_129.

Hopkins M, Hopkins H, Sothers C. Nocturnal pollination of Parkia velutina by Megalopta bees in Amazonia and its possible significance in the evolution of chiropterophily. J Trop Ecol. 2000;16(5):733-46. https://doi.org/10.1017/S0266467400001681.

Howell AD, Alarcón R. Osmia bees (Hymenoptera: Megachilidae) can detect nectar-rewarding flowers using olfactory cues. Anim Behav. 2007;74(2):199-205. https://doi.org/10.1016/j.anbehav.2006.11.012.
Huang M, Sanchez-Moreiras AM, Abel C, Sohrabi R, Lee S, Gershenzon $\mathrm{J}$, et al. The major volatile organic compound emitted from Arabidopsis thaliana flowers, the sesquiterpene (E)- $\beta$-caryophyllene, is a defense against a bacterial pathogen. New Phytol. 2012;193(4):9971008. https://doi.org/10.1111/j.1469-8137.2011.04001.x.

Junker RR, Gershenzon J, Unsicker SB. Floral odor bouquet loses its ant repellent properties after inhibition of terpene biosynthesis. J Chem Ecol. 2011;37(12):1323-31. https://doi.org/10.1007/s10886-0110043-0.

Karunanithi PS, Zerbe P. Terpene synthases as metabolic gatekeepers in the evolution of plant terpenoid chemical diversity. Front Plant Sci. 2019;10:1166. https://doi.org/10.3389/fpls.2019.01166.

Kelber A, Warrant EJ, Pfaff M, Wallén R, Theobald JC, Wcislo WT, et al. Light intensity limits foraging activity in nocturnal and crepuscular bees. Behav Ecol. 2006;17(1):63-72. https://doi.org/10.1093/beheco/ arj001.

Klatt BK, Burmeister C, Westphal C, Tscharntke T, von Fragstein M. Flower volatiles, crop varieties and bee responses. PLoS One. 2013;8(8):e72724. https://doi.org/10.1371/journal.pone.0072724.

Klein AM, Vaissière BE, Cane JH, Steffan-Dewenter I, Cunningham SA, Kremen $\mathrm{C}$, et al. Importance of pollinators in changing landscapes for world crops. Proc Biol Sci. 2007;274(1608):303-13. https://doi. org/10.1098/rspb.2006.3721.

Knauer AC, Schiestl FP. Bees use honest floral signals as indicators of reward when visiting flowers. Ecol Lett. 2015;18(2):135-43. https:// doi.org/10.1111/ele.12386.

Knoll F, Santos LM. Orchid bee baits attracting bees of the genus Megalopta (Hymenoptera, Halictidae) in Bauru region, São Paulo, Brazil: abundance, seasonality, and the importance of odors for dim-light bees. Rev Bras Entomol. 2012;56(4):481-8. https://doi.org/10.1590/ S0085-56262012000400013.

Knudsen JT, Eriksson R, Gershenzon J, Ståhl B. Diversity and distribution of floral scent. Bot Rev. 2006;72(1):1-120.

Knudsen JT, Tollsten L, Ervik F. Flower scent and pollination in selected neotropical palms. Plant Biol. 2001;3(6):642-53. https://doi.org/ 10.1055/s-2001-19366.

Kobayashi K, Arai M, Tanaka A, Matsuyama S, Honda H, Ohsawa R. Variation in floral scent compounds recognized by honeybees in Brassicaceae crop species. Breed Sci. 2012;62(4):293-302. https:// doi.org/10.1270/jsbbs.62.293.

Krug C, Cordeiro GD, Schäffler I, Silva CI, Oliveira R, Schlindwein C, et al. Nocturnal bee pollinators are attracted to guarana flowers by their scents. Front Plant Sci. 2018;9:1072. https://doi.org/10.3389/ fpls.2018.01072.

Kullenberg B. New observations on the pollination of Ophrys L. (Orchidaceae). Zoon. 1973;(Suppl 1):9-13.

Kunze J, Gumbert A. The combined effect of color and odor on flower choice behavior of bumble bees in flower mimicry systems. Behav Ecol. 2001;12(4):447-56. https://doi.org/10.1093/beheco/12.4.447.

Laloi D, Pham-Delègue MH. Bumble bees show asymmetrical discrimination between two odors in a classical conditioning procedure. J Insect Behav. 2004;17(3):385-96. https://doi.org/10.1023/B:JOIR. 0000031538.15346.e1.

Lange BM, Ahkami A. Metabolic engineering of plant monoterpenes, 
sesquiterpenes and diterpenes--current status and future opportunities. Plant Biotechnol J. 2013;11(2):169-96. https://doi.org/10.1111/ pbi. 12022

Liao P, Hemmerlin A, Bach TJ, Chye ML. The potential of the mevalonate pathway for enhanced isoprenoid production. Biotechnol Adv. 2016;34(5):697-713. https://doi.org/10.1016/j.biotechadv.2016.03. 005 .

Lunau K, Maier E. Innate colour preferences of flower visitors. J Comp Physiol A. 1995;177(1):1-19. https://doi.org/10.1007/BF00243394.

Majetic CJ, Raguso RA, Ashman TL. The sweet smell of success: floral scent affects pollinator attraction and seed fitness in Hesperis matronalis. Funct Ecol. 2009;23(3):480-7. https://doi.org/10.1111/j. 1365-2435.2008.01517.x.

Martín ML, San Román L, Domínguez A. In vitro activity of protoanemonin, an antifungal agent. Planta Med. 1990;56(1):66-9. https://doi. org/10.1055/s-2006-960886.

Meagher RL Jr. Trapping noctuid moths with synthetic floral volatile lures. Entomol Exp Appl. 2002;103(3):219-26.

Mena Granero A, Egea Gonzalez FJ, Guerra Sanz JM, Martínez Vidal JL. Analysis of biogenic volatile organic compounds in zucchini flowers: identification of scent sources. J Chem Ecol. 2005;31(10):2309-22. https://doi.org/10.1007/s10886-005-7103-2.

Michener CD. The bees of the world. 2nd ed. Baltimore: Johns Hopkins University Press; 2007.

Michener CD. The bees of the world. Baltimore: Johns Hopkins University Press; 2000.

Milet-Pinheiro P, Ayasse M, Dobson HE, Schlindwein C, Francke W, Dötterl S. The chemical basis of host-plant recognition in a specialized bee pollinator. J Chem Ecol. 2013;39(11-12):1347-60. https:// doi.org/10.1007/s10886-013-0363-3.

Minckley RL, Roulston T. Incidental mutualisms and pollen specialization among bees. In: Ollerton J, Waser NM, editors. Plant-pollinator interactions: from specialization to generalization. Chicago: University of Chicago Press; 2006. p. 69-98.

Muhlemann JK, Klempien A, Dudareva N. Floral volatiles: from biosynthesis to function. Plant Cell Environ. 2014;37(8):1936-49. https:// doi.org/10.1111/pce.12314.

Muth F, Papaj DR, Leonard AS. Bees remember flowers for more than one reason: pollen mediates associative learning. Anim Behav. 2016;111:93-100. https://doi.org/10.1016/j.anbehav.2015.09.029.

Newsholme C. Willows: the genus Salix. Portland: Timber Press; 1992.

Paldi N, Zilber S, Shafir S. Associative olfactory learning of honeybees to differential rewards in multiple contexts--effect of odor component and mixture similarity. J Chem Ecol. 2003;29(11):2515-38. https://doi.org/10.1023/a:1026362018796.

Parachnowitsch AL, Raguso RA, Kessler A. Phenotypic selection to increase floral scent emission, but not flower size or colour in bee-pollinated Penstemon digitalis. New Phytol. 2012;195(3):667-75. https://doi.org/10.1111/j.1469-8137.2012.04188.x.

Paulus HF, Gack C. Pollinators as prepollinating isolation factors: evolution and speciation in Ophrys (Orcffldaceae). Isr J Bot. 1990;39(12):43-79.

Pazouki L, Niinemets Ü. Multi-substrate terpene synthases: their occurrence and physiological significance. Front Plant Sci. 2016;7:1019. https://doi.org/10.3389/fpls.2016.01019.

Peled-Zehavi H, Oliva M, Xie Q, Tzin V, Oren-Shamir M, Aharoni A, et al. Metabolic engineering of the phenylpropanoid and its primary, precursor pathway to enhance the flavor of fruits and the aroma of flowers. Bioengineering (Basel). 2015;2(4):204-12. https://doi. org/10.3390/bioengineering2040204.

Pichersky E, Raguso RA. Why do plants produce so many terpenoid compounds? New Phytol. 2018;220(3):692-702. https://doi. org/10.1111/nph.14178.

Pinzauti M. Kiwi pollination: several ways of increasing the activity of honeybees. Acta Hortic. 1990;282:149-50. https://doi.org/10.17660/ ActaHortic.1990.282.18.

Poinar GO Jr, Danforth BN. A fossil bee from Early Cretaceous Burmese amber. Science. 2006;314(5799):614. https://doi.org/10.1126/science. 1134103 .

Potts SG, Imperatriz-Fonseca V, Ngo HT, Biesmeijer JC, Breeze TD, Dicks LV, et al. The assessment report of the Intergovernmental Science-Policy Platform On Biodiversity And Ecosystem Services (IP$\mathrm{BES}$ ) on pollinators, pollination and food production. Bonn: Intergovernmental Science-Policy Platform on Biodiversity and Ecosystem Services; 2016. p. 3-25.

Proctor M, Yeo PF, Lack A. The natural history of pollination. London: Harper Collins Publishers; 1996. p. 479.

Raguso RA, Levin RA, Foose SE, Holmberg MW, McDade LA. Fragrance chemistry, nocturnal rhythms and pollination "syndromes" in Nicotiana. Phytochemistry. 2003;63(3):265-84. https://doi.org/10. 1016/s0031-9422(03)00113-4.

Raguso RA, Willis MA. Synergy between visual and olfactory cues in nectar feeding by nave hawkmoths, Manduca sexta. Anim Behav. 2002;64(5):685-95. https://doi.org/10.1006/anbe.2002.4010.

Raguso RA. Wake up and smell the roses: the ecology and evolution of floral scent. Annu Rev Ecol Evol Syst. 2008;39:549-69. https://doi. org/10.1146/annurev.ecolsys.38.091206.095601.

Ramya M, Kwon OK, An HR, Park PM, Baek YS, Park PH. Floral scent: regulation and role of MYB transcription factors. Phytochem Lett. 2017;19:114-20. https://doi.org/10.1016/j.phytol.2016.12.015.

Robertson G, Griffiths D, Woodford J, Birch A. Changes in the chemical composition of volatiles released by the flowers and fruits of the red raspberry (Rubus idaeus) cultivar glen prosen. Phytochemistry. 1995;38(5):1175-9. https://doi.org/10.1016/0031-9422(94)00782-O.

Robertson HM, Wanner KW. The chemoreceptor superfamily in the honey bee, Apis mellifera: expansion of the odorant, but not gustatory, receptor family. Genome Res. 2006;16(11):1395-403. https://doi. org/10.1101/gr.5057506.

Rodriguez-Saona C, Parra L, Quiroz A, Isaacs R. Variation in highbush blueberry floral volatile profiles as a function of pollination status, cultivar, time of day and flower part: implications for flower visitation by bees. Ann Bot. 2011;107(8):1377-90. https://doi.org/10.1093/ aob/mcr077.

Rohmer M. The discovery of a mevalonate-independent pathway for isoprenoid biosynthesis in bacteria, algae and higher plants. Nat Prod Rep. 1999;16(5):565-74. https://doi.org/10.1039/a709175c.

Schäffler I, Steiner KE, Haid M, van Berkel SS, Gerlach G, Johnson SD, et al. Diacetin, a reliable cue and private communication channel in a 
specialized pollination system. Sci Rep. 2015;5:12779. https://doi. org/10.1038/srep 12779 .

Schiestl FP, Ayasse M. Post-pollination emission of a repellent compound in a sexually deceptive orchid: a new mechanism for maximising reproductive success? Oecologia. 2001;126(4):531-4. https://doi. org/10.1007/s004420000552.

Schiestl FP, Johnson SD. Pollinator-mediated evolution of floral signals. Trends Ecol Evol. 2013;28(5):307-15. https://doi.org/10.1016/j. tree.2013.01.019.

Tatsuka K, Suekane S, Sakai Y, Sumitani H. Volatile constituents of kiwi fruit flowers: simultaneous distillation and extraction versus headspace sampling. J Agric Food Chem. 1990;38(12):2176-80. https:// doi.org/10.1021/jf00102a015.

Theis N. Fragrance of Canada thistle (Cirsium arvense) attracts both floral herbivores and pollinators. J Chem Ecol. 2006;32(5):917-27. https://doi.org/10.1007/s10886-006-9051-x.

Tollsten L, Knudsen JT. Floral scent in dioecious Salix (Salicaceae)- a cue determining the pollination system? Plant Syst Evol. 1992;182(3):229-37. https://doi.org/10.1007/BF00939189.

Tsirakoglou V, Thrasyvoulou A, Hatjina F. Techniques to increase the attractiveness of kiwi flowers to honey bees. Acta Hortic. 1997;444: 439-52. https://doi.org/10.17660/ActaHortic.1997.444.68.

Twidle AM, Mas F, Harper AR, Horner RM, Welsh TJ, Suckling DM. Kiwifruit flower odor perception and recognition by honey bees, Apis mellifera. J Agric Food Chem. 2015;63(23):5597-602. https://doi. org/10.1021/acs.jafc.5b01165.

Tzin V, Galili G. New insights into the shikimate and aromatic amino acids biosynthesis pathways in plants. Mol Plant. 2010;3(6):956-72. https://doi.org/10.1093/mp/ssq048.

Wcislo WT, Tierney SM. Behavioural environments and niche construction: the evolution of dim-light foraging in bees. Biol Rev Camb Phi- los Soc. 2009;84(1):19-37. https://doi.org/10.1111/j.1469-185X. 2008.00059.x.

Whitney HM, Kolle M, Andrew P, Chittka L, Steiner U, Glover BJ. Floral iridescence, produced by diffractive optics, acts as a cue for animal pollinators. Science. 2009;323(5910):130-3. https://doi.org/10. 1126/science.1166256.

Williams IH, Pickett J, Martin A. The Nasonov pheromone of the honeybee Apis mellifera L. (Hymenoptera, Apidae). Part II. Bioassay of the components using foragers. J Chem Ecol. 1981;7(2):225-37. https://doi.org/10.1007/BF00995745.

Williams N. Floral fragrances as cues in animal behavior. Handb Exp Pollinat Biol. 1983:50-72.

Williams NH, Whitten WM. Orchid floral fragrances and male euglossine bees: methods and advances in the last sesquidecade. Biol Bull. 1983;164(3):355-95. https://doi.org/10.2307/1541248.

Wright GA, Schiestl FP. The evolution of floral scent: the influence of olfactory learning by insect pollinators on the honest signalling of floral rewards. Funct Ecol. 2009;23(5):841-51. https://doi.org/10.1111/ j.1365-2435.2009.01627.x.

Wright GA, Skinner BD, Smith BH. Ability of honeybee, Apis mellifera, to detect and discriminate odors of varieties of canola (Brassica rapa and Brassica napus) and snapdragon flowers (Antirrhinum majus). J Chem Ecol. 2002;28(4):721-40. https://doi.org/10.1023/a:1015232608858.

Wu S, Schalk M, Clark A, Miles RB, Coates R, Chappell J. Redirection of cytosolic or plastidic isoprenoid precursors elevates terpene production in plants. Nat Biotechnol. 2006;24(11):1441-7. https://doi. org/10.1038/nbt1251.

Yoo H, Widhalm JR, Qian Y, Maeda H, Cooper BR, Jannasch AS, et al. An alternative pathway contributes to phenylalanine biosynthesis in plants via a cytosolic tyrosine: phenylpyruvate aminotransferase. Nat Commun. 2013;4:2833. https://doi.org/10.1038/ncomms3833. 